\title{
Species of the diatom taxa Aulacodiscus and Trinacria with biostratigraphic utility in Palaeogene and Neogene North Sea sediments
}

\author{
Alexander G. Mitlehner ${ }^{1, \mathrm{a}}$ \\ ${ }^{1}$ Department of Geological (now Earth) Sciences, University College London, London, WC1E 6BT, UK \\ ${ }^{\mathrm{a}}$ current address: Greene's Tutorial College, Oxford, OX1 1BP, UK \\ Correspondence: Alexander G. Mitlehner (alexander.mitlehner@greenes.org.uk)
}

Received: 30 August 2018 - Revised: 10 March 2019 - Accepted: 12 March 2019 - Published: 29 May 2019

\begin{abstract}
Species of Aulacodiscus and Trinacria, two important marine diatom genera with biostratigraphic utility in offshore North Sea exploration and onshore correlation, are identified, described and emended and the North Sea microfaunal zonation scheme is revised accordingly. Occurring mainly as pyritised diatom moulds or steinkerns, detailed scanning electron microscope (SEM) analysis of several specimens, formerly in open nomenclature, has allowed the correct taxonomic identification of pyritised morphologies found to belong to the genus Aulacodiscus, including A. allorgei, A. heterostictus, A. insignis, A. singilewskyanus, A. subexcavatus and $A$. suspectus. The important marker species Trinacria regina is emended. SEM studies, using specimens preserved in pyrite and original silica, have shed further light on the varying forms and frustule morphology of Trinacria regina so that valves and frustules formerly thought to represent separate species are now found to be grouped within this taxon; SEM studies have shown that many of these variations represent different valves within a chain, whilst others may signify ecophenotypic variants. Emendments are therefore made to clarify the taxonomic status of different variants within T. regina, important in the Palaeocene-Eocene boundary interval onshore and offshore such as the Sele and Balder formations and the Fur Formation diatomite of Jutland, Denmark. Species of taxa formerly in open nomenclature are now assigned to Aulacodiscus insignis, which are important offshore markers in offshore late Oligocene to early Miocene sediments in northwest Europe.
\end{abstract}

\section{Introduction}

Marine diatoms have long been known to occur, often in large numbers, at various intervals in the Late Cretaceous to Neogene offshore sedimentary sequences of the North Sea Basin and related onshore sediments in northwest Europe (Heiberg, 1863; Grunow, 1866; Shrubsole and, Kitton, 1881; Wick, 1943-1950; Benda 1965, 1972; Egger et al., 2000; Homann 1991; King and Hughes, 1983; Malm et al., 1984; Mitlehner, 1994, 1996; Thyberg et al., 1999; Van Eetvelde et al., 2004; Richardt and Sheldon, 2014; Sheldon et al., 2018), Russia (Glezer et al., 1974; Oreshkina and Oberhänsli, 2003; Strel'nikova et al., 2004; Aleksandrova et al., 2012; Oreshkina and Radionova, 2014), the North Atlantic (Thomas and Gradstein, 1981), the Norwegian Sea (Scherer and Koç, 1996), and Arctic Canada (McNeill, 1990). Of- ten these diatoms occur in pyritised form, either as casts or steinkerns, and this has hampered species identification in the majority of cases (Simon and Bartenstein, 1962; Thomas and Gradstein, 1981; Hughes, 1981; King, 1983; McNeill, 1990). However, more recent studies using detailed scanning electron microscope (SEM) analysis and careful comparison with published monographs and collections in the Natural History Museum and elsewhere have enabled the taxonomic identification of these morphologies (Mitlehner, 1994, 1996, 1997; Bidgood et al., 1999; Van Eetvelde and Cornet, 2002; Van Eetvelde and Dupuis, 2005; Mitlehner and Hart, 2010; De Jonghe et al., 2011). This paper examines species from Aulacodiscus Ehrenb. and Trinacria Heiberg which occur within these intervals and are important in offshore exploration biostratigraphy. Both these genera are heavily silicified with distinctive features enabling identification to genus level; how- 


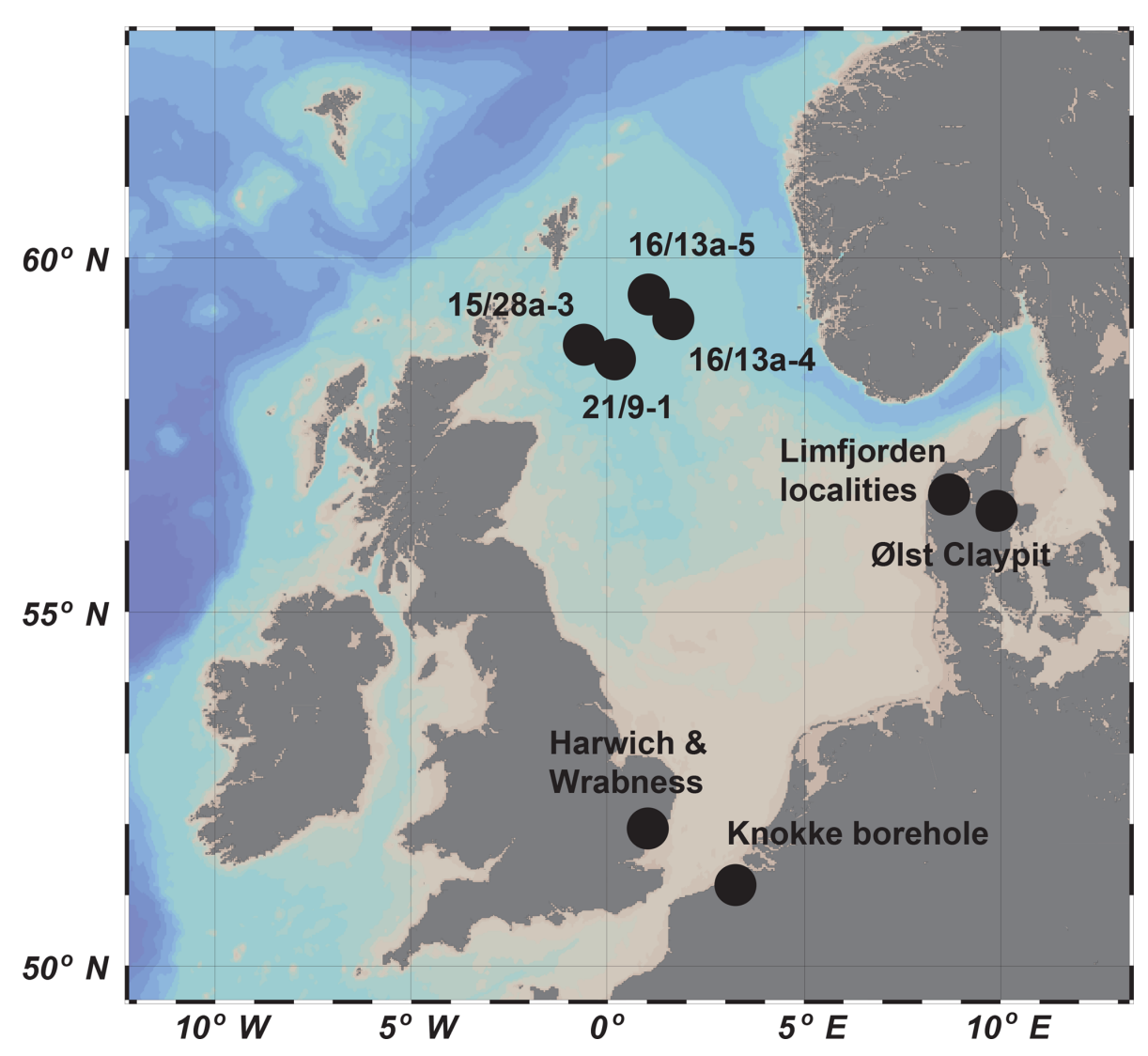

Figure 1. Sample localities in and around the North Sea Basin.

ever, as most biostratigraphers who encounter these forms are trained in foraminifera, ostracods and palynology, the identification of these forms has tended to be somewhat haphazard, with many in-house diatom identification schemes. The few published references have left them in open nomenclature (see Hughes, 1981; King, 1983). This paper redresses this issue, building on previous studies by Mitlehner (1994, 1996), Mitlehner and Hart (2010), and Bidgood et al. (1999).

\section{Material and methods}

Specimens forming the basis of this study came from offshore oil well samples processed and analysed from BP (British Petroleum) wells 15/28a-3, 21/9-1, 16/13a-4 and 16/13a-5, central North Sea (Fig. 1). Standard diatom recovery techniques (Battarbee 1986) were initially attempted on samples from these wells, but recovery was extremely poor because the vast majority of diatoms in the lithologies encountered (mainly muddy claystones, with some volcanic ash and glass shards in the Palaeocene-Eocene boundary interval; see Mudge and Bujak, 1996) occur in pyritised form; hydrogen peroxide is known to corrode pyrite, and so standard micropalaeontological techniques were implemented, including boiling samples in water with sodium hydroxide and wet-sieving to remove the finest clay (less than $63 \mu \mathrm{m}$ ), oven-drying and then dry-sieving into different size fractions.

Further specimens were examined from the BP collection of diatom morphotypes (now held in the Jageillonian University, Krakow, Poland; Michael A. Kaminski, personal communication, 2017) in addition to comparative material, including type slides and the Homann Collection (including processed and cleaned phials and slides) originating from the region of Limfjorden, Jutland, in Denmark (see Supplement), and housed in the British Museum (Natural History Museum, London). Electron micrographs of specimens from all the aforementioned localities were taken using the Zeiss DSM 940 scanning electron microscope in the Micropalaeontology Unit, Department of Geological Sciences, UCL, as well as the Hitachi S-800 field emission SEM at the British Museum (NHM).

\section{Results and interpretation: pyritised diatom occurrences and palaeoenvironments}

Many of the diatoms recovered in this study were found to be infilled or replaced by pyrite $\left(\mathrm{FeS}_{2}\right)$. The process of pyritisation has been the subject of several studies (see De Jonghe et al., 2011) and involves anoxic or dysaerobic environmental conditions, which are known to have occurred in and around 


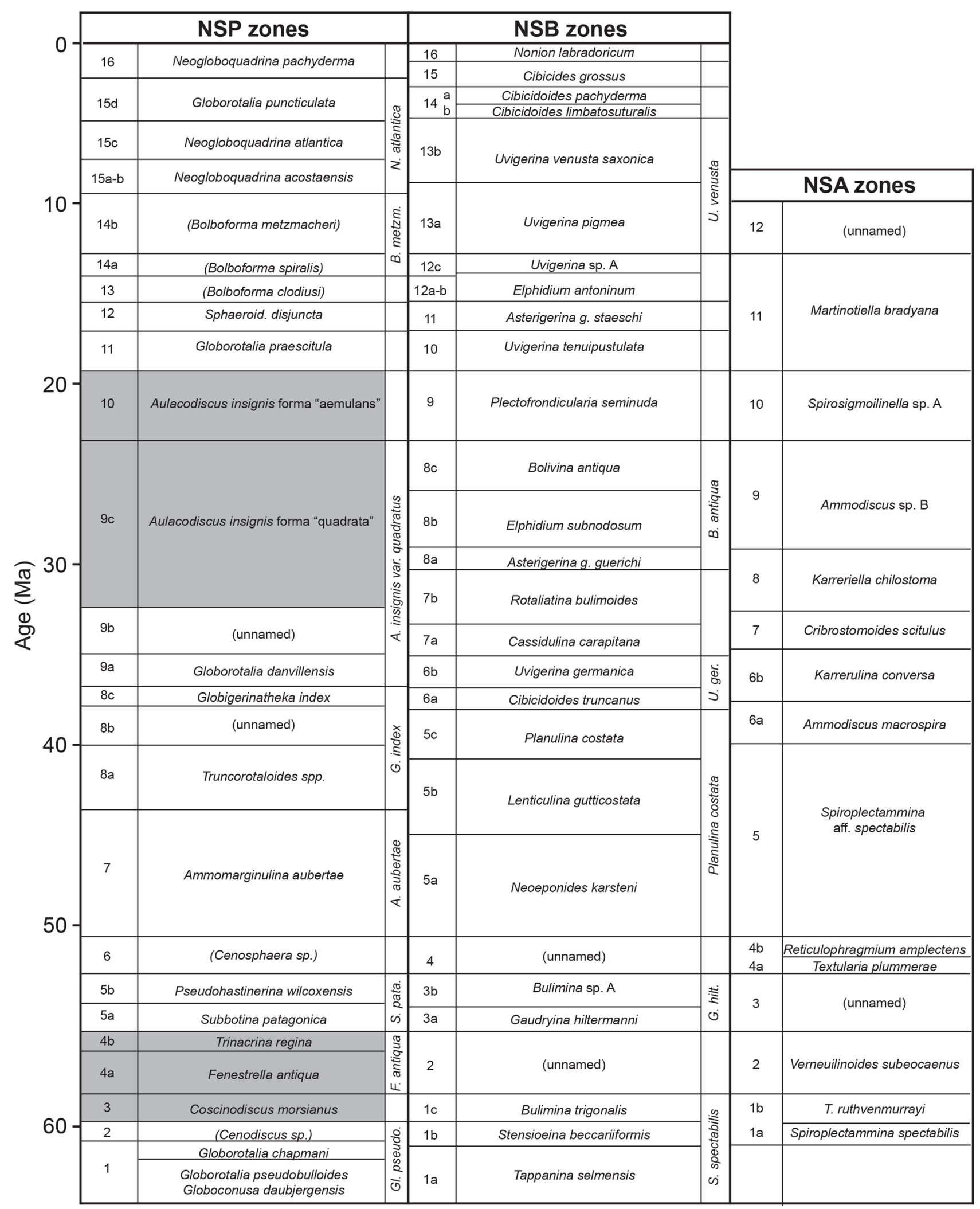

Figure 2. North Sea micropalaeontological zonation including diatoms (after King 1989). 


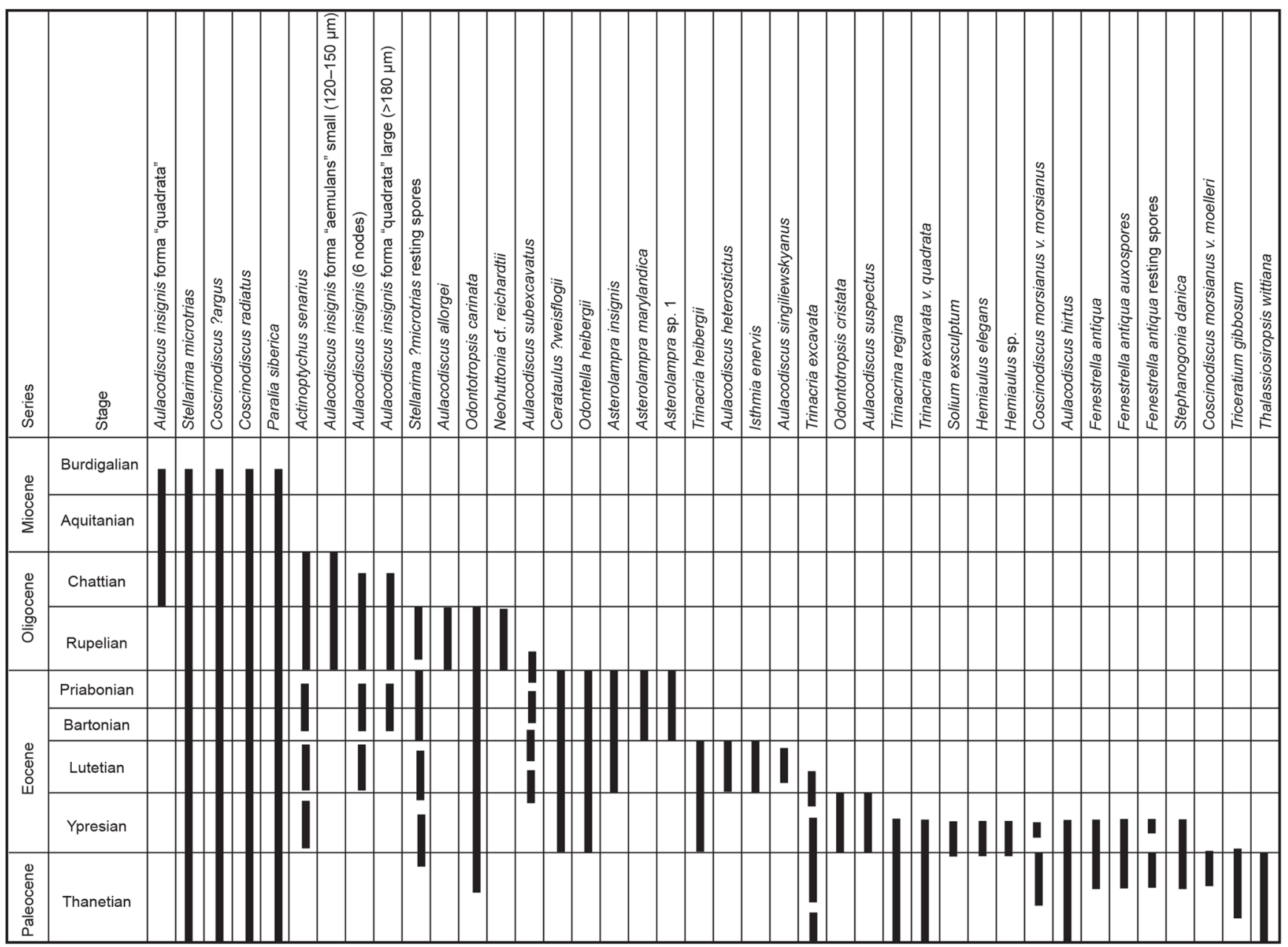

Figure 3. Range chart of more important diatom taxa occurring in pyritised form in North Sea Palaeogene to early Neogene sediments.

the North Sea Basin and its vicinity during various intervals in the Palaeogene and Neogene. Laminated mudstones, often co-occurring with pyrite either as discrete crystals or as overgrowths or as complete replacement of shells or diatom frustules, attest to these conditions which hampered the occurrence and/or preservation of calcareous microfossils such as foraminifera and nannoplankton, normally used by biostratigraphers for age identification of offshore strata in hydrocarbon exploration (see King, 1983, 1989). Restricted circulation processes involving seasonal, monsoon-driven upwelling leading to sporadic basin eutrophication and watercolumn stratification during and after the Palaeocene-Eocene Thermal Maximum (PETM; see Westerhold et al., 2009) are thought to account for the widespread proliferation of siliceous microfossils in northwest Europe and elsewhere. A later period of biosiliceous accumulation occurred during the late Oligocene to early Miocene, which was a prolonged period of weaker circulation favouring low-oxygen conditions with increased organic and terrigenous run-off from rapidly uplifting and eroding land-masses generated during the Miocene climatic optimum (Herold et al., 2012). This led to increased sedimentation rates and nutrient availability in shallow coastal regions and, as a result, massive and sustained diatom bloom events (and other siliceous microfossils such as silicoflagellates and ebridians) are recorded and provide basin-wide biostratigraphic markers (King, 1983, 1989; Mitlehner 1994; Thyberg et al., 1999; Dykbjaer et al., 2012; Sheldon et al., 2018). Figure 2 shows important diatoms in the North Sea micropalaeontological zonation and includes several taxa identified herein, in addition to others described previously (Mitlehner, 1994, 1996; Bidgood et al., 1999); Fig. 3 is a range chart of the more important diatom taxa encountered in Palaeogene and early Neogene sediments in the North Sea.

\section{Systematics}

Melosirales Crawford, in Round et al., 1990

Aulacodiscaceae (Schütt) Lemmermann, 1903 


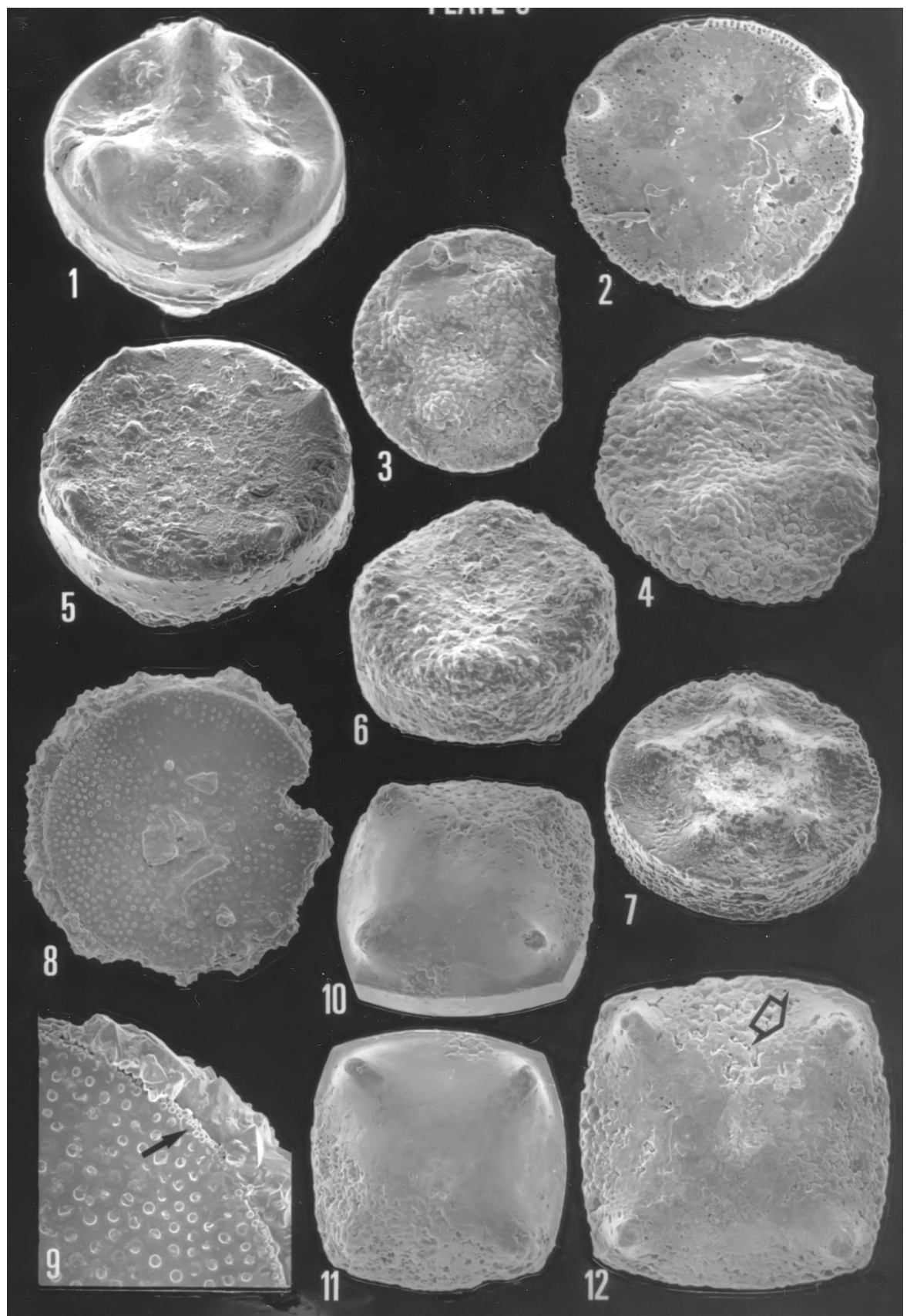

Plate 4. Aulacodiscaceae. NB all specimens pyritised. (1) Aulacodiscus subexcavatus Hustedt, (AGM 129) diameter 160 $\mu$ m. Oblique valve view. BP well 208/15a-1, 1220 m (core), lower Eocene. (2) Aulacodiscus heterostictus Barker and Meakin, (AGM 130) diameter 150 $\mu$ m. Valve view. BP well 16/16a-3, $1322.7 \mathrm{~m}$ (core), mid Eocene. (3-4) Aulacodiscus allorgei Chenevière. (3) (AGM 131) diameter 180 $\mu \mathrm{m}$. Valve view. BP well 3/25-1, $2162 \mathrm{~m}$ (core), lower Oligocene. (4) Oblique valve view of (3). (5-6, 10-12) Aulacodiscus insignis Hustedt. (5-6) Morphotype "aemulans". (5) (AGM 132) diameter $250 \mu \mathrm{m}$. Oblique valve view. BP well 16/16a-3, $1322.7 \mathrm{~m}$ (core), upper Oligocene. (6) (AGM 133) diameter $130 \mu \mathrm{m}$. Oblique valve view. BP well 15/28a-3, 3580', lower mid Miocene. (7) Aulacodiscus singiliewskyanus Barker and Meakin. (AGM 134) diameter $260 \mu \mathrm{m}$. Oblique valve view. BP well 208/15-1, $1315 \mathrm{~m}$ (SWC), middle Eocene. (8-9) Aulacodiscus suspectus Schmidt. (8) (AGM 135) diameter $140 \mu \mathrm{m}$. Valve view. Note raised, pustular areolae on valve face. BP well 21/9-1, 2122 m, uppermost Palaeocene. (9) Detail of (8). Width of view $40 \mu \mathrm{m}$. Note smaller areolae at valve margin (arrow). (10-12) Aulacodiscus insignis Hustedt. (10-12) Morphotype “quadrata”. (10) (AGM 136) diameter $180 \mu \mathrm{m}$. Oblique valve view. BP well 21/296-7, 5280', lower Oligocene. (11) Valve view of (10). (12) (AGM 137) diameter $225 \mu \mathrm{m}$. Valve view. Note hexagonal areolae (arrow). BP well 21/10-1, 5060', lower Oligocene. 


\section{Generic remarks}

A single genus represents this family, which is distinguished by its distinctive marginal processes. Species are known from the Upper Cretaceous (Campanian) to the present day. Modern species are attached, epiphytic and indicative of shallow marine conditions. (Round et al., 1990, p. 188).

Aulacodiscus Ehrenberg, 1844

\section{Description}

Cells are solitary, mostly circular in valve view, rarely quadrate, with conspicuous marginal nodes or processes (rimoportulae) usually extending on the valve exterior as hyaline tubes and on the interior as horseshoe-shaped slits. Valve with a circular hyaline area at the valve centre from which rows of mostly loculate areolae radiate in sectors with a hyaline ray leading to each marginal process. Valves often dissimilar, with one valve lacking the conspicuous marginal processes. The valve surface is often corrugated and the valve mantle narrow and mostly separated from the valve face by a marginal ridge. The areolae are closed by cribra externally and open internally by large foramina. Some species have a single layer pierced by areolae with cribra.

\section{Discussion}

A benthic genus with many fossil species, ranging from Upper Cretaceous (Campanian) to Holocene. Difficulties in distinguishing species were commented on in the extensive review of Burke and Woodward (1963-1974), in particular the fact that some species, including those encountered in North Sea Palaeogene and Neogene sediments, possess dissimilar valves (heterovalvy), which has caused taxonomic problems where whole frustules are not preserved intact. A recent morphological study of some of these taxa has resolved some of these issues (Strel'nikova et al., 2004). A number of species of Aulacodiscus occur in the Palaeogene of northwest Europe (including the North Sea, Norwegian Sea and West Shetland Basin) in pyritised form, some of which form useful stratigraphic markers. The taxonomic identity of these taxa was revealed through SEM studies and comparisons with specimens held in the collections of the Natural History Museum by Mitlehner (1994), refining the earlier work of King (1983) which highlighted their importance as stratigraphic markers in the Oligocene and Miocene but which had them left in open nomenclature (e.g. "Diatom spp. 3, 4 \& 5").

\section{Stratigraphic range}

Late Cretaceous (Campanian: Tapia and Harwood, 2002) to Holocene. Although long-ranging, important stratigraphic marker species occur in the Eocene, Oligocene and Miocene of NW Europe and elsewhere, several are described more accurately in pyritised form for the first time.
Aulacodiscus allorgei Chenevière (1934: 106, plate 8, fig. 2). Plate 1, figs. 3-4.

Type: California Academy of Sciences collection, San Francisco. CAS 612240: slide 581087. Not examined by present author but illustrated by Strel'nikova et al. (2004, figs. 57-65).

Illustrations: Barker and Meakin (1947: 175, plate 24, fig. 2); Burke \& Woodward (1971: 332-3); Thomas \& Gradstein (1981: 19, plate 3.1, figs. 1-4, as Coscinodiscus sp. 1, pyritised form); King (1983: 20, plate 1, figs. 5, 6, as diatom sp. 4, pyritised form); Strel'nikova et al. (2004: 298, figs. 57-65).

\section{Description}

Valves are circular, diameter $100-150 \mu \mathrm{m}$, with four (rarely five) broad, ligulate rimoportulae projecting radially outwards from dilated clear central areas at the angles of the polygonal elevation, with the outer part nearly horizontal and extending generally as far as the margin of the valve. Surface with a flat marginal zone thence sloping sharply to a more or less elevated large polygonal (usually quadrate) central zone with slightly convex sides, rounded angles somewhat distant from the margin, and sometimes a slight central depression. Markings small polygonal cellules, five to six in $10 \mu \mathrm{m}$.

\section{Remarks}

Ross and Sims (1970) conducted a scanning electron microscope study of $A$. allorgei and described the fine structure of the valve. Burke and Woodward (1963-1974, p. 323) commented on the variation between specimens of the outline of the central elevation, which may be straight, convex or concave. They also remarked on the general difficulty in distinguishing A. allorgei from A. hirtus Barker and Meakin, with which it often co-occurs in the "Kamishev" deposit (now Kamyshlov, Sverdlovskaya District, late Palaeocene to middle Eocene). Strel'nikova et al. (2004) conducted a detailed study of diatoms from the Russian Collection in the California Academy of Sciences and also figured and described A. allorgei from the Sengilei diatomite (considered to be earliest Eocene; Oreshkina and Oberhänsli, 2003).

Aulacodiscus heterostictus Barker et Meakin (1944: 251, plate 38, fig. 2). Plate 1, fig. 2.

Synonym: Aulacodiscus schmidtii Witt (1885: 157 (21), plate 7, figs. 1,1; Glezer 1974 plate XIV, figs. 3, 4.).

\section{Description}

Valves are circular, diameter $150 \mu \mathrm{m}$, with three rimoportulae, each forming tubes with a slender stem and an enlarged, widened terminal portion. Surface depressed at centre, rising gently towards rimoportulae, descending to a flat border with 
centre. Markings different in three concentric zones: (1) a small rounded central zone with few conspicuous rounded areolae scattered irregularly in translucent furrows; (2) areolae being closer together in outer half of row, remotely spread in inner half; (3) border with radiating rows of confluent quadrate cellules extending more or less over edge of raised surface (Barker and Meakin, 1944, 251).

\section{Remarks}

Barker and Meakin (1944) made comparisons with A. schmidtii Witt and A. septus A. Schmidt. Aulacodiscus heterostictus is distinguished by the markings of the median zone and the round instead of triangular central zone. One specimen of $A$. schmidtii figured by Glezer et al. (1974, plate XIV, fig. 3) has striking similarities to A.heterostictus; A. schmidtii may be a synonym of $A$. septus as specimens of all "taxa" appear in the same material ("Singliliewsky", almost certainly the Sengilei diatomite; Strel'nikova et al., 2004). Strel'nikova et al. (2004) considered that these are synonyms and that variants ("formae") with four, five or six rimoportulae are morphological variants within this assemblage as they occur in the same outcrop and there is no age variation between them.

Found in the middle Eocene of the North Sea in pyritised form. Known informally as "Sp. CN 22" (British Petroleum).

\subsection{Occurrence (this study)}

BP well 16/16a-3, 1322.7m (core), central North Sea from the BP collection of diatom morphotypes (now housed in the Jagiellonian University, Krakow, Poland). North Sea (Mitlehner, 1994; British Petroleum, unpublished data).

Aulacodiscus insignis Hustedt in A. Schmidt et al. (1944: plate 458, figs. 3-6). Plate 1, figs. 5, 6, 1012.

Synonym: Aulacodiscus aemulans. Barker \& Meakin (1947: 176, plate 24, fig. 1).

Illustrations: Burke \& Woodward (1971: 332); King \& Hughes (1983, as Diatom sp. 5: 20, plate 1, figs. 5, 6, pyritised form).

\section{Description}

Valves round or quadrate with convex sides and with a narrow hyaline margin, diameter $125-250 \mu \mathrm{m}$. Surface with large polygonal elevation, angles usually four, rounded, extending nearly to margin, sides arcuate, with steep slopes to margin. Rimoportulae four to five short stout tubes, projecting outwardly from small clear areas at angles of elevation. Markings on top of elevation subcircular or polygonal cellules, 2.5 in $10 \mu \mathrm{m}$, arranged in radiating lines. Cellules with internal pores, forming pseudoloculate structure, arranged in horizontal lines; larger cellules with eyespot and puncta, 20 in $10 \mu \mathrm{m}$.

\section{Discussion}

Barker and Meakin (1947) were unaware of Aulacodiscus insignis, described by Hustedt (1944), when they described Aulacodiscus aemulans; this may have been due to a lack of scientific correspondence between them during World War 2. Later, Burke and Woodward (1971, p. 332) discussed the synonymy and used Hustedt's name Aulacodiscus insignis. A. aemulans Barker and Meakin is therefore a junior synonym. SEM studies of specimens of $A$. insignis yielded evidence that supports its subdivision into three variants. Further studies of well-preserved specimens (in original opaline silica) are required in order to formally erect varieties and so the most important of these are referred to here under morphotypes "aemulans" and "quadrata".

Aulacodiscus insignis morphotype "aemulans"; Plate 1, figs. 5, 6 .

Illustration: King (1983, plate 1, fig. 4 as Diatom sp. 4, pyritised form).

\section{Description}

Valves round, diameter 100-120 $\mu \mathrm{m}$; large, polygonal elevation on valve face with four to five rimoportulae. Cellules often indistinct, with meshwork of small areolae visible, five to six in $10 \mu \mathrm{m}$.

King (in King and Hughes, 1983) named the pyritised form with five nodes or processes "Diatom sp. 4" and described it thus: "its valve is circular, very thin and slightly convex in girdle view, but with five small equally spaced projections present near the valve margin" (King. 1983, p. 20).

\section{Remarks}

Valves with five processes commonly occur in the upper Oligocene and lower Miocene of the central North Sea (King, 1983; Schiøler et al., 2007).

\section{Occurrence (this study)}

BP well 3/25-1, 2162m (core), central North Sea from the BP collection of diatom morphotypes (now housed in the Jagiellonian University, Krakow, Poland).

\section{Stratigraphic range}

Upper Oligocene to lower Miocene: North Sea (Mitlehner, 1994; Schiøler et al., 2007; this study). Sufficiently widespread to form a zonal marker for Zone NSP 10 in the North Sea microfaunal zonation of King (1983). Early 
Eocene: Russia, Volga Basin, Kamyshin Formation (Oreshkina and Aleksandrova, 2007); "Carlovo" and "Kamischev", now Kamyshlov, Sverdlovskaya District (Barker and Meakin, 1947; Burke and Woodward, 1963-1974).

Aulacodiscus insignis morphotype "quadrata"; Plate 1, figs. 10-12.

Synonym: Amphitetras subrotundata Janisch in A. Schmidt (1874-1959: plate 99, fig. 24).

Illustration: King \& Hughes (1983: plate 1, fig. 4 as Diatom sp. 3, pyritised form).

\section{Occurrence (this study)}

BP well 21/296-7, 5280', central North Sea from the BP collection of diatom morphotypes (now housed in the Jagiellonian University, Krakow, Poland).

\section{Emended description}

Valve quadrate in valve view, rectangular in girdle view, with heterovalvy. A clear angle of approximately $95^{\circ}$ occurs between the sides, to form developed corners. Mantle narrow, with a distinct flange which extends around the valve circumference. Four processes, clearly produced, project at an inward angle of $45^{\circ}$ at each corner, these are only present on one valve. Areolae large, hexagonal, five to six in $10 \mu \mathrm{m}$.

\section{Dimensions}

Valve diameter $120 \mu \mathrm{m}$ (upper Oligocene and lower Miocene forms); $180 \mu \mathrm{m}$ (upper Oligocene forms).

\section{Remarks}

Aulacodiscus insignis morphotype "quadrata" has never been recovered in original opaline silica (Philip Copestake, personal communication, 1995). However, a remarkably similar form was illustrated in Schmidt's Atlas (1874-1959, plate 99, fig. 24). It was collected during the Gazelle expedition of 1874-8 by A. Janisch, who figured a drawing of a diatom which he referred to as Aulacodiscus subrotundata in a set of plates, distributed privately in 1904 and without any text. Other diatom taxa depicted from the same expedition have a distinctly modern aspect to them (Patricia A. Sims, personal communication, 1994) although it is possible that the highly robust frustules were reworked from older sediment, as some species from the Gazelle expedition are also known from the upper Eocene of Barbados (Rattray, 1889). In the absence of an accurate and valid description, it was decided to formally erect a new variety herein.

\section{Occurrence (this study)}

BP well 15/28a-3; BP well 21/296-7; BP well 21/10-1, central North Sea, from the BP collection of diatom morphotypes (now housed in the Jagiellonian University, Krakow, Poland).

\section{Stratigraphic range}

Lower Oligocene to lower Miocene: North Sea (Mitlehner, 1994; Schiøler et al., 2007; this study). This highly distinctive diatom has a sufficiently widespread occurrence to form a zonal marker (Zone NSP 9) in the North Sea microfaunal zonation of King (1983). Larger specimens (up to $180 \mu \mathrm{m}$ ) are restricted to the upper Oligocene; smaller specimens range throughout the upper Oligocene and lower Miocene (Schiøler et al., 2007).

Aulacodiscus singiliewskyanus Barker et Meakin (1944: 251, plate 38, fig. 3.). Plate 1, fig. 7.

Synonym: Aulacodiscus archangelskianus Witt. Strel'nikova et al. (2004: figs. 39-46).

Illustrations: Ross \& Sims (1970: 57, plate 6, figs. 3334). Mitlehner \& Hart (2010: plate 2, fig. 1, pyritised form).

\section{Description}

Valve circular. Processes five, rarely four and six, projecting from small circular clear areas on broad radial inflations extending to the border from the angles of a polygonal elevation. Primary rays distinct, extending from the clear areas on the inflations to the sides of a small roughly outlined polygonal clear area at the centre of the surface. Markings small rounded granules, close together in radial rows, confused near the centre. In the compartments between the processes, the surface near the border is depressed and then rises into an inwardly curved narrow mound.

\section{Remarks}

A form always encountered in pyritised form in the North Sea and adjacent onshore deposits (Mitlehner and Hart, 2010), usually with five rays but sometimes with six. All of the features described by Barker and Meakin (1944) are clearly visible except for the primary rays, which extend along the inflations in unpyritised specimens.

Barker and Meakin (1944) and Ross and Sims (1970) commented on the close resemblance of this species to A. tuberculatus Pantocsek, a form found in the same material, from Sengilei in the Volga Basin, Russia. Ross and Sims (1970) considered that the two may be endmembers of a continuous series, a phenomenon often encountered in diatom populations. Strel'nikova et al. (2004) regarded 
A. tuberculatus and A. archangelskianus Witt as senior synonyms of A. sengiliewskyanus Barker et Meakin. However, A. archangelskianus ranges from the Late Cretaceous to the late Palaeocene whereas A. singiliewskyanus has been found exclusively in deposits of middle Eocene age (Mitlehner, 1994; Mitlehner and Hart, 2010). Accordingly, the latter designation is kept for the morphologies encountered in this interval during the present study.

\section{Occurrence (this study)}

BP well 208/15-1, 1315 m, northern North Sea in the BP collection of diatom morphotypes (now housed in the Jagiellonian University, Krakow, Poland).

\section{Stratigraphic range}

Middle Eocene: Russia, Volga Basin, Sengilei (Barker and, Meakin, 1944; Ross and Sims, 1970). Middle Eocene: Marsh Farm Formation, Isle of Wight, UK (Mitlehner and Hart, 2010).

Aulacodiscus subexcavatus Hustedt (1944: plate 460, figs. 3-13). Plate 1, Fig. 1.

(Nom. nud.: Craspedoporus actinoptychoides Glezer et al. (1974, plate XXXII, fig. 10)).

Illustrations: Benda (1965, 171, plate 22, figs. 6-7; non plate 23, fig. 1). Mitlehner \& Hart (2010, plate 2, Figs. 2, 3, pyritised form).

\section{Emended description}

Forms with three radial elevations, at the summits of which are processes. Valve margin has small radial striae, central area plain. Surface with radial rays of round, free pores, five to six in $10 \mu \mathrm{m}$. This morphology has gross similarities with A. excavatus A. Schmidt. It is distinguished by its more prominent valve relief (strongly indented between the elevations) and the situation of its large, pear-shaped processes. The latter are positioned close to the valve margin (translated from Benda, 1965, p. 171-2).

\section{Dimensions}

Valve diameter $85-120 \mu \mathrm{m}$.

\section{Remarks}

A. subexcavatus appears to be conspecific with Craspedoporus actinoptychoides Glezer. The latter was figured from the Eocene of Russia by Glezer et al. (1974) but not described in detail. Glezer's figured specimen is strongly suggestive of $A$. subexcavatus, the type specimen of which came from the area of the Volga Basin (Hustedt, 1944). The name appears to be based on Auliscus actinoptychoides published 10 years earlier by Glezer (Glezer and Posnova, 1964, p. 64, Taf. III, fig. 1, which is the same illustration as Glezer, 1974, plate XXXII, fig. 10). However, there is no publication that makes the formal transfer from Auliscus to Craspedoporus and so this name is thus considered invalid (David M. Williams, personal communication, 2013).

\section{Occurrence (this study)}

BP well 208/15-1, 1220 m, Horda Formation, northern North Sea from the BP collection of diatom morphotypes (now housed in the Jagiellonian University, Krakow, Poland).

\section{Range}

Lower Eocene: Denmark, Fur Formation (Benda, 1972); North Germany (Benda, 1965); Russia, "Kamischev" now Kamyshlov, Sverdlovskaya District (Hustedt, 1944; Glezer et al., 1974); Eocene: Horda Formation, North Sea Basin (Mitlehner, 1994); middle Eocene: Marsh Farm Formation, Isle of Wight, UK (Mitlehner and Hart, 2010).

Aulacodiscus suspectus A. Schmidt (1876, plate 36, figs. 17, 18). Plate 1, figs. 8, 9.

Synonyms: Aulacodiscus imperfectus Grunow (1884: 69); Coscinodiscus josefinus Grunow (1884: 69).

Illustrations: Benda (1972: plate 2, fig. 12); Homann (1991: p. 37, plate 6, figs. $1-5$; plate 7 , figs. $1-3,5$ ).

\section{Description}

Valve outline circular, flat or slightly convex. Central area poorly defined, with no central rosette. Areolae polygonal, arranged in radial lines away from the centre (translated from Homann, 1991, p. 38). Shape flattened, discoidal with a low mantle. Central area hyaline. Areolae arranged radially in rows, two to seven in $10 \mu \mathrm{m}$ near the valve centre, declining markedly in size at the margin $(9-10$ in $10 \mu \mathrm{m})$. An area of larger areolae occurs mid-valve. Between two and six hyaline rays are visible between the rows of areolae, at the end of each is a labiate process. Micro-labiate processes are sometimes visible both at the valve margin and on the valve face (Plate 1, fig. 9).

\section{Dimensions}

Valve diameter $140 \mu \mathrm{m}$.

\section{Remarks}

A. suspectus resembles Aulacodiscus probabilis A. Schmidt by the lack of valve face undulation but differs from it by the smaller size of the external expression of the rimoportulae. The synonymy of this taxon reflects the fact that the true delineation between Coscinodiscus and Aulacodiscus is 
not perfectly clear at present and requires further research (Strel'nikova et al., 2004). To date, no formal comparison of the holotypes of Aulacodiscus suspectus and Coscinodiscus josefinus has been carried out. Strel'nikova (1997) erected a new genus, Moisseevia, based on a superficially similar taxon from Palaeogene deposits in Russia. However, this is morphologically much closer to Aulacodiscus probabilis as it has larger expression of external fultoportulae (see Oreshkina and Aleksandrova 2007, plate II, 11).

In pyritised specimens, the areolae are filled in with pyrite to form raised "bosses" or papillae, arranged radially over the valve surface in the same manner as the original areolae. This is a useful feature for identification during the picking of microfauna from micropalaeontological residues. Other features, such as the micro-labiate processes, are only readily observable via SEM.

\section{Occurrence (this study)}

BP wells 15/28a-3 and 21;/9-1, central North Sea, Sele Formation; Knudeklint Member, Fur Formation, Denmark.

\section{Range}

Lower Eocene: Denmark, Fur Formation (Benda, 1972; Homann, 1991; Mitlehner, 1996); North Sea, Sele and Balder formations (Mitlehner, 1994, 1996); Russia, Barents Sea (Grunow, 1884); Sengiley (Oreshkina and Oberhänsli, 2003).

Order Hemialulales Round et Crawford, in Round et al. 1990

Family Hemiaulaceae Heiberg, 1863

Genus Trinacria Heiberg, 1863

\section{Generic remarks}

A very characteristic triangular or quadrate genus, often confused with Triceratium, from which it is distinguished by its corner spines, larger size and radial areolae. Some species of Trinacria display considerable morphological variation, in both valve shape and ornament. The extensive and varied synonymy for some species reflects this, and it is only recently that these variations have been studied in detail. SEM examination of well-preserved, non-pyritised specimens from the Fur Formation by Mitlehner (1994) showed that many of the "varieties" of the species figured by Grunow, Schmidt and others and discussed by Homann (1991) are in fact different valves which interlock within a chain. An exclusively fossil genus, with species ranging from the Upper Cretaceous (Maastrichtian) to upper Miocene (Sims and Ross, 1988). Following the investigations of Mitlehner (1994), both the description and synonymy of Trinacria are emended herein.
Trinacria regina (Heiberg) Homann, emend. Plate 2, figs. 1-11. Heiberg (1863, 50, plate 3.)

Synonymy:

Trinacria regina var. punctulata Grunow (1884: 67., fig. 15).

Trinacria regina var. valida Grunow (1884: 67. plate B, fig. 58).

Trinacria wittii. Schmidt (1886: plate 96, fig. 1; plate 97, fig. 2, 2a).

Trinacria jordanii. Schmidt (1893: plate 204, fig. 6).

Trinacria antiqua Pantocsek (1905: Vol. 3, 115, plate 32, fig. 456).

Triceratium sp. 1 Bettenstaedt et al., in Simon and Bartenstein (1962: 358, plate 20, fig. 1, pyritised form).

Trinacria aff. wittii. Malm et al. (1984:158, fig. 8i., pyritised form).

Illustrations: Kitton (1871: 101, plate 2, figs. 17); Grunow (1884: 67); Hustedt (1930, fig. 528). Proshkina-Lavrenko (1949: Vol. 1, plate 5, fig 16; Vol. 2, plate 193, plate 60, fig. 6); Benda (1972: 256, plate 1, figs. 8-9; plate 4, fig. 38); Bignot (1981: 117, plate 1, figs. 9-11.(pyritised form); Gombos (1984: 501, plate 3, fig. 1); Malm et al. (1984:158, fig. 8j); Homann (1991: 124-6, plate 50, figs. 1-7; plate 51, figs. 1-7); Oreshkina and Oberhänsli (2003: plate 4, s); Aleksandrova et al. (2012: plate II, 1); Oreshkina and Radionova (2014: plate 8: 10, 11); Richardt and Sheldon (2014: fig. $4, \mathrm{j}, \mathrm{k})$

\section{Emended and translated description}

Valve tripolar, with more or less concave, rarely almost straight sides with broadly rounded poles, drawn out into a short, narrow point. Valve centre flat to highly convex, specimens with the latter sometimes having a concave depression at top; rare teratological specimens with an eccentric curvature; central elevation substantially lower than the elevations which project from the corners. Elevations straight, narrow, usually tall but sometimes very short. Occasionally the apices of the elevations have a thickened, rounded top. Horn apices with two to three short strengthened spines, circa 8-15 $\mu \mathrm{m}$ long; these interlock with similar spines on adjacent cells to form an enclosed, interlocking chain. Valve margin sharply pronounced, distinctly alar (winged), proceeding more or less parallel to the base of the mantle valve. The "wings" are drawn up to the height of the elevations. Valve mantle low, 5-25 $\mu \mathrm{m}$ high, shaped around the base of the valve. The sharp edge of the mantle, combined with the 


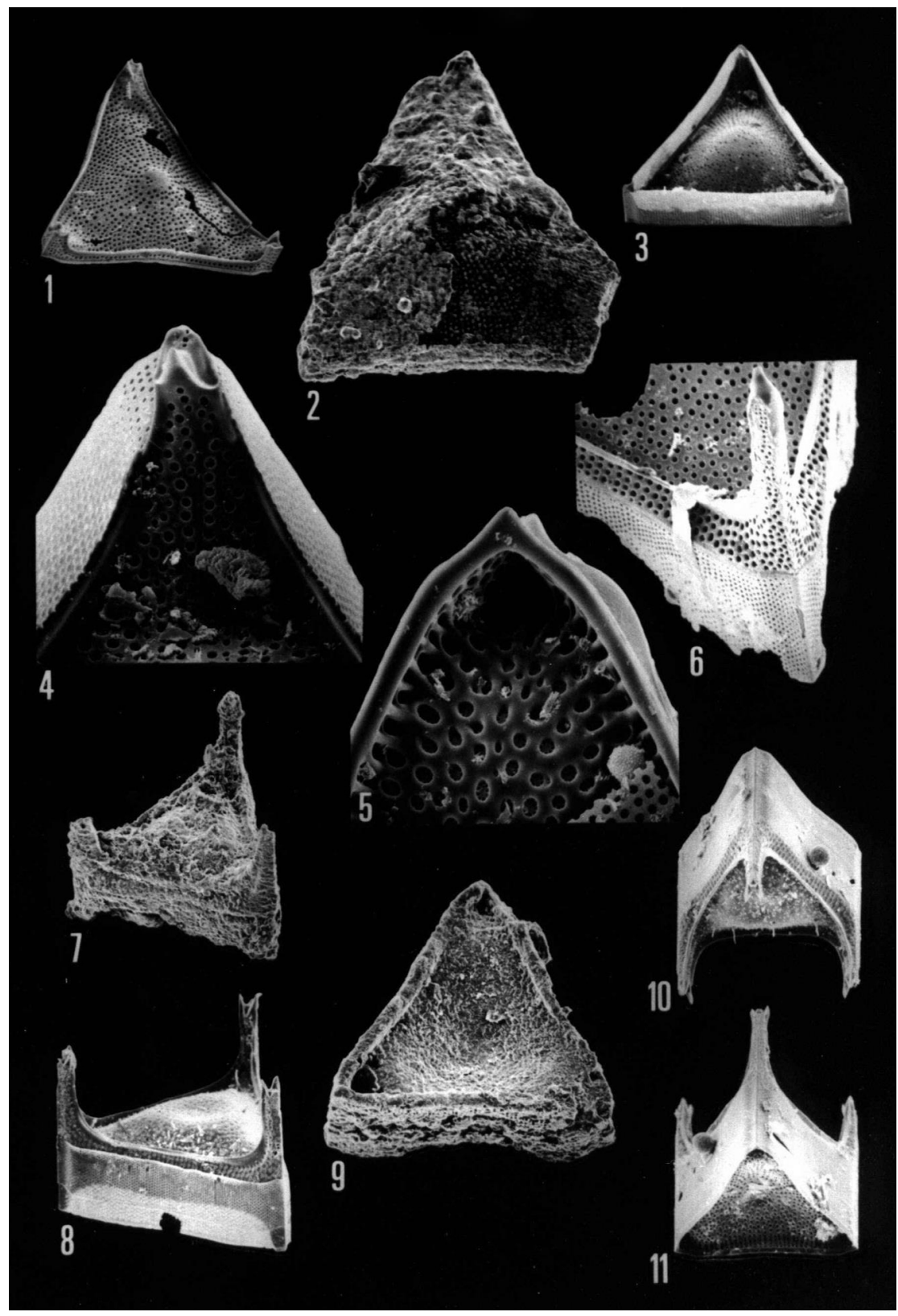

Plate 5. Trinacria regina. NB pyritised and non-pyritised specimens. (1-11) Trinacria regina (Heiberg) Homann. (1) Length to apices $100 \mu \mathrm{m}$. Specimen preserved in original opaline silica. Oblique valve view, inside of separation valve. Note central node and radiating areolae. Natural History Museum collections ("Fur Nykøbing"), lowermost Eocene. (2) (AGM 149) Width of specimen $80 \mu \mathrm{m}$. Pyritised specimen. Note radiating areolae on bottom right of specimen, infilled by pyrite. Rest of specimen covered with overpyrite. BP well 15/28a-3, 6460', uppermost Palaeocene. (3) Length to apices $110 \mu \mathrm{m}$. Specimen preserved in original opaline silica. Oblique valve view, showing intact girdle band around edge of valve. Natural History Museum, Homann collection ("D 330"), lowermost Eocene. (4) Detail of (4). Width of view $40 \mu \mathrm{m}$. Short apical spine, which interlocks with linking valve above (compare with 8). (5) Width of view $25 \mu \mathrm{m}$. Specimen preserved in original opaline silica. Detail of separation valve, at base of complete frustule. Note cribra infilling pores. Natural History Museum, Homann collection ("D 330"), lowermost Eocene. (6) Width of view $30 \mu \mathrm{m}$. Specimen preserved in original opaline silica. Detail of apex. Linking valve, with long spine, attached to separation valve (partially obscured by girdle band). Natural History Museum, Homann collection ("D 330"), lowermost Eocene. (7) (AGM 150) Length to apices $80 \mu \mathrm{m}$. Oblique view of two joined valves, replaced by pyrite. Note linking valve above separation valve. Ølst, Denmark (“Ølst B”), lowermost Eocene. (8) Length to apices $80 \mu \mathrm{m}$. Specimen preserved in original opaline silica. Compare with (7). Natural History Museum, Homann collection ("D 330"), lowermost Eocene. (9) (AGM 151) Length to apices $70 \mu \mathrm{m}$. Pyritised specimen. Base of deeply concave separation valve. Ølst, Denmark ("Ølst B”), lowermost Eocene. (10) Length to apices $80 \mu \mathrm{m}$. Specimen preserved in original opaline silica. Oblique view of top of frustule, with long spines which connect with a similar frustule to form a chain. Natural History Museum, Homann collection (“D 330”), lowermost Eocene. (11) Basal view of (10). 
extended alar mantle, often gives the impression of a "double edge" when seen in valve view. Detailed SEM examination of well-preserved specimens in original opaline silica from the Fur Formation of northern Denmark (see outcrop photographs, figs. 2-d) during the study of Mitlehner (1994) shows that many of the varieties of this species, figured in LM (light microscope) only by Homann, are in fact different valves which interlock within a chain (Plate 2, figs. 10-11). In addition, some of the areolae are seen to be ornamented with small spines (see Round et al., 1990, p. 269, fig. h). The "alar" projections of Homann are more properly termed marginal ridges (Patricia A. Sims, personal communication, 1994).

\section{Dimensions}

Length between poles variable, from 60 to $230 \mu \mathrm{m}$. Areolae three to six in $10 \mu \mathrm{m}$, becoming smaller up the elevations.

\section{Remarks}

Trinacria regina displays considerable morphological variation, both in valve shape and ornament. The extensive and varied synonymy for this species reflects this, and it is only relatively recently that these variations have been studied in detail (Homann 1991, Mitlehner 1994; this study). Homann (1991) considered that specimens with an eccentric central areolation (see Homann 1991, plate 50, fig. 7) should be regarded as teratological (i.e. ecophenotypic) variants, whilst other morphologies formerly assigned species names ("jordanii", "punctulata", "wittii”) are now regarded as varieties of $T$. regina.

\section{Discussion}

This species is one of the most abundant taxa in both offshore and onshore samples studied and often dominates assemblages in the lowermost Eocene Balder (offshore) and Fur (onshore) formations (see Mitlehner, 1996, for biostratigraphic correlation of these and other age-equivalent strata around the North Sea Basin). Although often pyritised or calcified, enough of the diagnostic characters described above are preserved to allow confident species designation, and although only the bases of the corner elevations are often preserved, in some cases complete projections are seen with the whole specimen completely replaced by pyrite (Plate 2, fig. 7; see De Jonghe et al., 2011, for a discussion on the pyritisation process). However, some detail such as rimoportulae (Plate 2, fig. 5) are not clear in pyritised specimens. In some cases the valves are deeply concave, which on closer inspection are separation valves, found at the terminal ends of each chain (Plate 2, fig. 10). In most cases the edge of the mantle is very prominent, appearing slightly concave in some specimens (Plate 2, fig. 1). Some specimens exhibit fine, radial striae on the valve face, originally named Tri- nacria jordanii by Schmidt and renamed "Typ jordanii" by Homann (Homann 1991, plate 51, fig. 5); others exhibit three radial, hyaline rays, which Homann termed "Typ wittii" after Benda's (1972) original description as Trinacria wittii. Malm et al. (1984, fig. 8j) figured the latter variant from an offshore oil well in the Norwegian Sector of the North Sea, in the Lower Eocene Balder Formation. In the lower part of the ageequivalent Fur Formation of Denmark (Knudeklint Member, Pedersen \& Surlyk 1983), T. regina is extremely abundant in some samples examined by the present author, particularly around ash layers -20 to -6 of Bøggild (1918), equivalent to the Knudeklint Member; this may be due to blooms during a period of intense eutrophication during the Initial Eocene Thermal Maximum (Schoon et al., 2015). In pyritised form, specimens have hitherto been designated as Triceratium sp. 1 Bettenstaedt et al., 1962 (Malm et al., 1984, fig. 8i). Other morphotypes in use in the offshore oil exploration industry are variants of T. regina (for example, "Triceratium spp. 30, $31,55,58$ " of Robertson Research and others).

\section{Occurrence (this study)}

Lower Eocene: BP wells 15/28a-3 and 21;/9-1, central North Sea, Sele Formation; base of Ieper Formation, Knokke borehole, Belgium; Ølst Formation, Denmark; upper part of the Knudeklint Member, Fur Formation, Denmark.

\section{Range}

Palaeocene: Cape Basin, South Atlantic (Gombos 1984, DSDP 73); Volga Basin, Russia (Glezer et al., 1974). Kerteminde Marl (Bignot 1983). Lower Eocene: Barents Sea (Grunow 1884); Denmark, Fur Formation (Benda 1972; Homann 1991); Sengiley, Middle Povolzhie (Oreshkina and Oberhänsli 2003); North Sea, Sele Formation (King 1983; Malm et al. 1984; Mitlehner 1996); England, London Clay, Harwich Member (Shrubsole and Kitton 1881; King 1981); North Germany, Unter Eozän (Benda 1965); Northern France, Sparnacian (Bignot 1983; Van Eetvelde and Cornet 2002); southern North Sea (Hughes 1981).

\section{Discussion and conclusions}

The current study has demonstrated that it is possible to identify pyritised diatoms to species level using SEM studies and by comparison with specimens preserved in opaline silica and illustrations of these. The species of Aulacodiscus and Trinacria identified and described here are well known stratigraphically to micropalaeontologists working on routine analysis of oil and gas exploration wells in and around the North Sea Basin, and it is to be hoped that the publication of the diatom taxa herein will lead to more standardised use of Linnean nomenclature in offshore studies, both published and in-house, as well as to further studies of Aulacodiscus insignis from offshore sediments of late Oligocene 
to early Miocene age so that this can be can be formally described and potentially split into different varieties. Wellpreserved specimens in their original opaline silica would be necessary in order to facilitate this. This has already occurred with several diatom species known in pyritised form throughout the North Sea and in related onshore sediments. Further publication of species will allow the identity of other pyritised morphologies to become established and enable a more refined correlation of in-house biozonation schemes with published data. One of the key diatom taxa known as an important biostratigraphic marker in offshore exploration for the Palaeocene-Eocene boundary interval and formerly known as Coscinodiscus sp. 1 Bettenstaedt was published formally in pyritised form by Bidgood et al. (1999) following on the earlier work of Mitlehner (1994). It was identified therein as a species of Fenestrella due to the presence of two lines of labiate processes on either side of the valve, together with a highly domed valve, a distinctive iridescent sheen, and a very large size (typically over $300 \mu \mathrm{m}$ in diameter). These characters enabled this taxon to be identified as Fenestrella antiqua (Grunow) Swatman, a species revised and described by Sims (1990). Other stratigraphically important taxa also found in the same interval were also identified therein and in Mitlehner (1996); tables showing the correct identity of several important pyritised diatom morphologies in offshore exploration were published in both papers and their use has steadily become more established in the industrial micropalaeontological community (Schiøler et al., 2007). It is hoped that the publication of further species in the present work will similarly enable further recognition of the true identity of several other diatom taxa well known to offshore biostratigraphers.

Data availability. This research draws on data from my $\mathrm{PhD}$ thesis, produced in 1994. The data exist in printed form as appendices to this thesis, which is available online (via free online registration) at https://ethos.bl.uk/OrderDetails.do?uin=uk.bl.ethos. 241823\T1\textquotedblright.

Supplement. The supplement related to this article is available online at: https://doi.org/10.5194/jm-38-67-2019-supplement.

Competing interests. The authors declare that they have no conflict of interest.

Acknowledgements. The author is indebted to Patricia Sims for her help, advice and encouragement for the duration of this and related studies on pyritised diatoms from North Sea Palaeogene and Neogene sediments, conducted as part of a $\mathrm{PhD}$ research programme. Her encyclopaedic knowledge of diatom taxa and the collections and publications housed in the Natural History Museum, Department of Life Sciences helped steer the author towards identifying the diatoms described above and elsewhere, thereby enabling their true identity to become established in pyritised form. Technical support was provided by Karen Childs, Geraldine Reid and staff in the Electron Microscope Unit at the Natural History Museum; further technical assistance was provided by James Davy and Toby Stiles in the Micropalaeontology Unit, Department of Geological (now Earth) Sciences, University College London. Claus Heilmann-Clausen (Aarhus University) took the author to the Ølst clay pit, Denmark, to sample for diatoms. The author acknowledges financial support provided by the Natural Environment Research Council and British Petroleum plc, who funded this work as part of a NERC/BP/NHM CASE Studentship Award. Helpful advice and comments on the paper were received from David M. Williams (Department of Life Sciences, Natural History Museum, London). Sev Kender is thanked for help with redrafting the figures and Emma Sheldon (GEUS) is thanked for helpful comments on the paper.

Review statement. This paper was edited by Sev Kender and reviewed by Claus Heilmann-Clausen and one anonymous referee.

\section{References}

Aleksandrova, G. N., Oreshkina, T. V., Iakovleva, A. I., and Radionova, E. P.: Late Paleocene-Early Eocene diatoms and dinocysts from biosiliceous facies of the Middle Trans Urals region, Stratigr. Geol. Corr., 20, 380-404, 2012.

Barker, I. W. and Meakin, S. H.: New genera and species of diatoms from Russia, Journal of the Quekett Microscopical Club, 4, 251 255, 1944

Barker, I. W. and Meakin, S. H.: Diatoms from Russian deposits, Journal of the Quekett Microscopical Club, 4, 175-178, 1947.

Battarbee, R. W.: Diatom analysis, Handbook of Holocene palaeoecology and palaeohydrology, 1, 527-570, 1986.

Benda, L.: Diatomeen aus dem Eozän Norddeutschlands, Paläont. Zeitschrift, 39, 165-187, 1965.

Benda, L.: The Diatoms of the Moler Formation of Denmark (Lower Eocene), in: First Symposium on Recent and fossil marine diatoms, edited by: Simonsen, R., Beiheft zur Nova Hedwigia, 39, 251-266, 1972.

Bidgood, M., Mitlehner, A. G., Jones, G. F., and Jutson, D.: Towards a stable and agreed nomenclature for North Sea Tertiary diatom floras - the "Coscinodiscus" problem, in: Biostratigraphy in Production and Development Geology, edited by: Jones, R. W. and Simmons, M. J., Geological Society Special Publications, 152, 139-153, 1999.

Bignot, G.: Les Lagunes Sparnaciennes: Une étape dans la conquête des eaux douces par les diatomêes, Revue de Micropaléontologie, 26, 15-21, 1983.

Bøggild, O. B.: Den vulkanske Aske i Moleret samt en Oversigt over Danmarks ældre Tertiærbjærgarter, 1918.

Burke, J. F. and Woodward, J. B.: A review of the genus Aulacodiscus, Staten Island Institute of Arts and Sciences, New York, 360 pp., 1963-1974.

Chenevriére, E.: Sur un dépôt fossile marin à diatomées situé à Kamischev (Russie centrale), Bulletin de la Société Française de Microscopie, 3, 103-107, pls 5-8., 1934. 
De Jonghe, A., Hart, M. B., Grimes, S. T., Mitlehner, A. G., Price, G. D., and Smart C. W.: Middle Eocene diatoms from Whitecliff Bay, Isle of Wight, England: stratigraphy and preservation, P. Geologist. Assoc., 122, 472-483, https://doi.org/10.1016/j.pgeola.2011.02.003, 2011.

Dybkjaer, K., King, C., and Sheldon, E.: Identification and characterisation of the Oligocene-Miocene boundary (base Neogene) in the eastern North Sea Basin - based on dinocyst stratigraphy, micropalaeontology and $\delta 13 \mathrm{C}$-isotope data, Palaeogeography, Palaeogeogr. Palaeocl., 363-364, 11-22, 2012.

Egger, H., Heilmann-Clausen, C., and Schmitz, B.: The Paleocene/Eocene boundary interval of a Tethyan deep-sea section and its correlation with the North Sea basin, Societe Geologique de France Bulletin, 171, 207-216, 2000.

Ehrenberg, C. G.: Einige vorläufige Resultate seiner Untersuchungen der ihm von der Südpolreise des Captain Ross, so wie von den Herren Schayer und Darwin zugekommenen Materialien über das Verhalten des kleinsten Lebens in den Oceanen und den grössten bisher zugänglichen Tiefen des Weltmeeres. Bericht über die zur Bekanntmachung Geeigneten Verhandlungen Der Königl. Preuss. Akademie Der Wissenschaften zu Berlin, 182207, 1844.

Fenner, J.: Diatoms of the Fur Formation, their taxonomy and biostratigraphic interpretation-results from the Harre borehole, Denmark, Aarhus Geoscience, 1, 99-163, 1994.

Gleser, S. I. and Stepanova, G. V.: Raschlenenie i korrelyatziya paleogenovykh otlojeniy Karskogo morya po diatomeyam i silikoflagellatam, (Subdivision and correlation of Kara Sea Paleogene deposits on the basis of diatoms and silicoflagellates), Regionalnaya Geologia i Metallogenia, 2, 148-153, 1994.

Glezer, S. I. and Posnova, A. N.: Diatomeae Novae Marinae ex Eoceno Kazachstaniae occidentalis, Novitates Systematicae plantarum non vascularum, Academia Scientiarum URSS, Inst. Botanicum Nomine V.L. Komarovii, Moscow, Leningrad (Nauka), 59-68, 1964.

Glezer, S. I.: Paleogene Diatoms, Fossil and modern diatoms of USSR, TI Edition “Nauka,” Leningrad, 109-147, 1974.

Gombos Jr., A. M.: Late Paleocene diatoms in the Cape basin, Initial Reports of the Deep Sea Drilling Project, 73, 495-511, 1984.

Grunow, A.: Moler aus Jütland, eingesandt von Th. Jensen, analisiert von A. Grunow, Hedwigia, 5, 145-146, 1866.

Grunow, A.: Die Diatomeen von Franz Josefs-Land, Denkschriften der Kaiserlichen Akademie der Wissenschaften, MathematischNaturwissenschaftliche Classe, Wien, 48, 53-112, 5 pls, 1884.

Heiberg, P. A. C.: Conspectus criticus diatomacearum danicarum: Kritisk Oversigt over De Danske Diatomeer, William Priors Forlag, Copenhagen, 135 pp., 1863.

Herold, N., Huber, M., Müller, R. D., and Seton, M.: Modeling the Miocene climatic optimum: Ocean circulation, Paleoceanography, 27, PA1209, https://doi.org/10.1029/2010PA002041, 2012.

Homann, M.: Die Diatomeen der Fur-Formation (Alt-tertiär) aus dem Limfjord-Gebeit, Nordjutland/Dänemark, Geologisches Jahrbuch, Reihe A, 123, 285 pp., 57 pl., 1991.

Hughes, M. J.: Contribution on Oligocene and Eocene microfossils from the southern North Sea, 111, in: Microfossils from Fossil and Recent Shelf Seas, edited by: Neale, J. W. and Brasier, M. D., Ellis Horwood, Chichester, 186-294, 1981.

Hustedt, F.: Atlas der Diatomaceen-Kunde, Reisland, 1944.
King, C. and Hughes, M. J.: Cainozoic Micropalaeontological Biostratigraphy of the North Sea, Institute of Geological Sciences Report 82/7, HMSO, London, 40 pp., 1983.

Lemmermann, E.: Das Phytoplankton des Meeres. II. Beitrag. Abhandlungen herausgegeben vom Naturwissenschaftlichen Verein zu Bremen, 17, 341-418, 1903.

McNeill, D. H.: Stratigraphy and paleocology of the Eocene Stellarima Assemblage zone (pyrite diatom steinkerns) in the Beaufort-Mackenzie basin, Arctic Canada, Bulletin of Canadian Petroleum Geology, 38, 17-27, 1990.

Malm, O. A., Christensen, O. B., Furnes, H., Løvlie, R., Rueslåtten, H., and Østby, K. L.: The Lower Tertiary Balder Formation: an organogenic and tuffaceous deposit in the North Sea region, in: Petroleum Geology of the North European Margin, edited by: Spencer, A., Johnsen, S. O., Mørk, A., Nysæther, E., Sognstad, P., and Spinnangr, A., Graham and Trotman, London, 149-170, 1984.

Mitlehner, A. G.: The occurrence and preservation of diatoms in the Palaeogene of the North Sea Basin, PhD Thesis, University College, University of London, 1994.

Mitlehner, A. G.: Paleoenvironments in the North Sea Basin around the Paleocene-Eocene boundary: evidence from diatoms and other siliceous rnicrofossils, in: Correlation of the Early Paleogene in Northwest Europe, edited by: Knox, R. W. O' B, Corfield, R. M., and Dunay, R. E., Geological Society Special Publication 101, 255-273, 1996.

Mitlehner, A. G.: Diatoms from the Olst Formation, Denmark: comparisons with assemblages from other localities in the North Sea Basin, in: Geology and Palaeontology of the Mo-Clay, edited by: Thomsen, E. and Pedersen, A. S., Aarhus Geoscience Special Volume 6, 28-29, 1997.

Mitlehner, A. G. and Hart, M. B.: The discovery of a Middle Eocene diatom flora from Whitecliff Bay, Isle of Wight England, in: Micropalaeontology, Sedimentary Environments and Stratigraphy: A Tribute to Dennis Curry (1912-2001), edited by: Whittaker, J. E. and Hart, M. B.: The Micropalaeontological Society Special Publications, 217-233, https://doi.org/10.1144/TMS004.9.1747602X, 2010.

Mudge, D. C. and Bujak, J. P.: An integrated stratigraphy for the Paleocene and Eocene of the North Sea, in: Correlation of the Early Paleogene in Northwest Europe, edited by: Knox, R.W.O'B., Corfield, R. M., and Dunay, R. E., Geological Society Special Publication, 101, 91-113, 1996.

Oreshkina, T. V.: New data on early Eocene diatom successions of the West Polar Urals margin: Biostratigraphic and paleogeographic implications, The Geological Society of Sweden, GFF, 122, 124-126, 2000.

Oreshkina, T. V. and Aleksandrova, G. N.: Terminal Paleocene of the Volga Middle Reaches: Biostratigraphy and Paleosettings, Stratigr. Geol. Korrelyatsiya, 15, 93-118, https://doi.org/10.1134/S0869593807020062, 2007.

Orseshkina, T. V. and Oberhänsli, H.: Diatom turnover in the early Paleogene diatomite of the Sengiley section, middle Povolzhie, Russia: A response to the initial Eocene thermal maximum?, Geological Society of America Special Papers, 369, 169-179, 2003.

Oreshkina, T. V. and Radionova, E. P.: Diatom record of the Paleocene-Eocene Thermal Maximum in marine paleobasins of Central Russia, Transuralia and adjacent regions, Nova Hedwigia, Beiheft, 143, 307-336, 2014. 
Pedersen, G. K. and Surlyk, F.: The Fur Formation, a late Paleocene ash-bearing diatomite from northern Denmark, Bulletin of the Geological Society of Denmark, 32, 43-65, 1983.

Rattray, J. A.: The revision of the genus Coscinodiscus Ehrb., and of some allied genera, Proceedings of the Royal Society of Edinburgh, 16, 449-692, 1889.

Richardt, P. A. and Sheldon, E.: Palynological and microfossil biostratigraphy and palaeoecology over the Paleocene-Eocene transition, Femern Bælt, northern Germany, Geological Survey of Denmark and Greenland Bulletin, 31, 35-38, 2014.

Ross, R. and Sims, P. A.: Studies of Aulacodiscus with the scanning electron microscope, Nova Hedwigia, Beiheft 45, 97-121, 1970.

Ross, R. and Sims, P. A.: Some genera of the Biddulphiaceae (diatoms) with interlocking linking spines, Bulletin of the British Museum, Natural History (Botany Series), 13, 277-381, 1985.

Round, F., Crawford, R. M. and Mann, D.: The Diatoms, Biology and Morphology of the Genera, Cambridge University Press, Cambridge, 782 pp., 1990.

Scherer, R. P. and Koç, N.: Late Paleogene diatom biostratigraphy and paleoenvironments of the northern Norwegian-Greenland Sea, in: Proc. ODP, Sci. Results, edited by: Thiede, J., Myhre, A. M., Firth, J. V., Johnson, G. L., and Ruddiman, W. F., College Station, TX (Ocean Drilling Program), 151, 75-99, 1996

Schiøler, P., Andsbjerg, J., Clausen, O. R., Dam, G., Dybkjær, K., Hamberg, L., Heilmann-Clausen, C., Johannesen, E. P., Prince, I., and Rasmussen, J. A.: Lithostratigraphy of the Palaeogenelower Neogene succession of the Danish North Sea, Geological Survey of Denmark and Greenland Bulletin, 12, 5-77, 2007.

Schmidt, A.: Atlas der Diatomaceen-Kunde, Started by A. Schmidt, continued by M. Schmidt, Fr. Fricke, O. Muller, H. Heiden and F. Hustedt, 481 plates, Leipzig, Berlin, 1874-1959.

Schoon, P. L., Heilmann-Clausen, C., Schultz, B. P., Sinninghe Damsté, J. S., and Schouten, S.: Warming and environmental changes in the eastern North Sea Basin during the Palaeocene-Eocene Thermal Maximum as revealed by biomarker lipids, Org. Geochem., 78, 79-88, https://doi.org/10.1016/j.orggeochem.2014.11.003, 2015.

Sheldon, E., Rasmussen, E. K., Dybkjær, K., Eidvin, T., Riis, F., and Eeibel, R.: Miocene oil-bearing diatom ooze from the North Sea, Geological Survey of Denmark and Greenland Bulletin, 41, 29-32, 2018.

Shrubsole, W. H. and Kitton, F.: The diatoms of the London Clay. With a list of species and remarks, Journal of the Royal Microscopical Society, 11, 381-387, 1881.

Simon, W. and Bartenstein, H.: Leitfossilien der Mikropaläontologie: ein Abriss, Berlin, Gebruder Borntraeger, 1962.
Sims, P. A.: The fossil diatom genus Fenestrella, its morphology, systematics and palaeogeography, Beiheft zur Nova Hedwigia, 100, 277-288, 1990.

Sims, P. A. and Ross, R.: Some Cretaceous and Palaeogene Trinacria (diatom) species, Bulletin of the British Museum, Natural History (Botany series), 18, HMSO, London, 275-322, 1988.

Strel'nikova, N. I.: A new genus Moisseevia (Bacillariophyta) from the Paleogene deposits of Russia, Botanicheskii Zhurnal Moskva then Sankt-Peterburg, 82, 119-121, 1997.

Strel'nikova, N., Fourtanier, E., and Kociolek, P.: Morphological studies of Aulacodiscus species from the "Russian collection" of the California Academy of Sciences, Diatom Research, 19, 238 310, 2004.

Tapia, P. M. and Harwood, D. M.: Upper Cretaceous diatom biostratigraphy of the Arctic archipelago and northern continental margin, Canada. Papers in the Earth and Atmospheric Sciences, 184, available at: http://digitalcommons.unl. edu/geosciencefacpub/184 (last access: 14 May 2019), 2002.

Thomas, F. C and Gradstein, F. M.: Tertiary subsurface correlations using pyritised diatoms, offshore eastern Canada, Current Research, Part B, Geological Survey of Canada, 81, 17-23, 1981.

Thyberg, B. I., Stabell, B., Faleide, Y. I., and Bjorlykke, K.: Upper Oligocene Diatomaceous Deposits in the Northern Nortn Sea- Silica Diagenesis and Paleogeographic Implications, Norsk. Geol. Tidskrift, 79, 3-18, 1999.

Van Eetvelde, Y. and Cornet, C.: Some Eocene species of marine pyritized diatoms in the core of Saint-Josse (France), Diatom Research, 17, 423-435, 2002.

Van Eetvelde, J. and Dupuis, C.: Biostratigraphical and paleoenvironmental study based on pyritized diatoms of the upper Paleocene-lower Eocene interval of the Saint-Josse core (France), Geobios, 38, 269-282, 2005.

Van Eetvelde, Y., Dupuis, C., and Cornet, C.: Pyritized diatoms: a good fossil marker in the Upper Paleocene-Lower Eocene sediments from the Belgian and Dieppe-Hampshire Basins, Netherlands Journal of Geosciences/Geologie en Mijnbouw, 83, 173178, 2004.

Westerhold, T., Röhl, U., McCarren, H. K., and Zachos, J. C.: Latest on the absolute age of the Paleocene-Eocene Thermal Maximum (PETM): new insights from exact stratigraphic position of key ash layers 119 and 217, Earth Planet. Sc. Lett., 287, 412-419, 2009.

Wick, W.: Mikrofaunische Untersuchungen des tieferen Tertiärs über ein Salzstock in der Nähe von Hamburg, Abhandlungen Senckenberg Natürischen Geschichte, 468, 40 pp., 1943-1950. 